\title{
The Destruction of Books by Traditionists
}

\section{La destrucción de libros por los tradicionistas}

\author{
Christopher Melchert \\ University of Oxford
}

\begin{abstract}
This paper is a survey of the destruction of books particularly by traditionists (collectors, transmitters, and critics of hadith) and particularly in the ninth century CE and before, offered as an addendum to Omar Ali de Unzaga's forthcoming study of book burning in Islam. The destruction of books from distrust of written transmission has been adequately brought out by Michael Cook. What I chiefly add to previous scholarly accounts are some additional examples, a brief consideration of destroying books for the sake of orthodoxy, and a better account of pious reasons for destroying books, which had much to do with distrust not of writing hadith but of teaching it as a temptation to pride and a distraction from weightier things.
\end{abstract}

Key words: Destruction of books; Distrust of written transmission; Traditionists; Teaching hadith.
Este artículo ofrece una panorámica de la destrucción de libros especialmente por parte de los tradicionistas (compiladores, transmisores, críticos del hadiz), especialmente en el siglo IX de la era cristiana y antes, que sirve como una adenda al estudio (en curso de publicación) de Omar Ali de Unzaga sobre la quema de libros en el islam. La destrucción de libros a causa de la desconfianza hacia la transmisión escrita ha sido analizada en profundidad por Michael Cook. Lo que me interesa añadir a la investigación previa son algunos ejemplos adicionales, unas breves consideraciones sobre la destrucción de libros en pro de la ortodoxia, y una mejor presentación de las razones piadosas para destruir libros, razones que tenían mucho que ver con la desconfianza no tanto de poner escrito el hadiz, sino de enseñarlo, en tanto que tentación para caer en la vanidad y distracción de asuntos más importantes.

Palabras clave: Destrucción de libros; desconfianza hacia la transmisión escrita; tradicionistas; enseñanza del hadiz.

Here is a survey of the destruction of books particularly by traditionists (collectors, transmitters, and critics of hadith) and particularly in the ninth century $\mathrm{CE}$ and before, offered as an addendum to Omar Ali de Unzaga's forthcoming study of book burning in Islam. The destruction of books from distrust of written transmission has been adequately brought out by Michael Cook. ${ }^{1}$ What I chiefly add to previous

\footnotetext{
${ }^{1}$ Cook, "The opponents of the writing of tradition in early Islam".
} 
scholarly accounts are some additional examples, a brief consideration of destroying books for the sake of orthodoxy, and a better account of pious reasons for destroying books, which had much to do with distrust not of writing hadith but of teaching it as a temptation to pride and a distraction from weightier things.

For most of the eighth century CE, it was controversial whether hadith should ever be written down. ${ }^{2}$ The technical language of hadith transmission stresses direct oral transmission. Hadith itself means 'utterance' and plainly corresponds to the oral law of the Rabbis as opposed to the written law (for the Rabbis, the Pentateuch; for Muslims, the Qur'ān). Rather than writing it down, one was supposed to hear it, keep it in one's memory, and then dictate in turn what one knew from memory. 'Do not write on my authority ('annī)', reads a prophetic hadith report in Muslim's Șahịh. 'Whoever writes down on my authority anything but the Qur'ān, let him erase it. Relate things on my authority orally (haddith $\bar{u}$ 'annī) without embarrassment. ${ }^{3}$ Ahmad ibn Hanbal relates five variants, in one of which Abu Hurayrah relates how he and some other Companions, on hearing the Prophet's prohibition, made a pile of their notes and burnt them. ${ }^{4} \mathrm{Abu}$ Dāwūd mentions an occasion when a Companion related a hadith report to the caliph $\mathrm{Mu}$ àwiyah, the caliph had someone write it down, then the Companion had it erased in obedience to the Prophet's prohibition. ${ }^{5}$

A great deal of theoretical literature on orality identifies its chief feature and advantage as the possibility of continually reshaping tradition

2 The controversy is splendidly surveyed by Cook, "The opponents of the writing". $V$. also the series of articles by Gregor Schoeler referred to by Cook, esp. "Die Frage der Schriftlichen oder mündlichen Überlieferung der Wissenschaften im frühen Islam" and "Schreiben und Veröffentlichen. Zu Verwendung und Funktion der Schrift in den ersten islamischen Jahrhunderten," also available in translation (by Uwe Vagelpohl) with additional notes (by James E. Montgomery) as The oral and the written in early Islam. His work has now culminated in Schoeler, The genesis of literature in Islam: from the aural to the read, rev. and trans. by Shawkat M. Toorawa. I tend to be more sceptical than Schoeler when it comes to the reliability of attributions to and biographical reports of the earliest figures, one reason for my discounting pressure from the Umayyad caliphs as an explanation for why the writing of hadith either became normal or met resistance.

${ }^{3}$ Muslim, Sahìh, Kitāb al-zuhd wa-l-raqà 'iq 16, bāb al-tathabbut fi kitābat al-hadìth, no 3004

${ }^{4}$ Ahmad ibn Hanbal, Musnad imām al-muhaddithīn, 3:12-13 = Ahmad ibn Hanbal, Musnad al-imām, ed. al-Arna'ūt, 17: 156-9; other parallels at Musnad, 3:12, 21, 39, $56=$ ed. al-Arna'üt, 17: 149-50, 151-2, 250-1, 443, 18:94, the third of which includes the description of burning.

${ }^{5}$ Abū Dāwūd, Sunan, Kitāb al-'ilm 3, bāb fì kitāb al-'ilm, no 3647. 
to suit the present moment. ${ }^{6}$ That a great deal of such reshaping took place in the course of transmitting hadith seems hard to deny. ${ }^{7}$ The tradition acknowledges that dictation from memory was liable to distortion. For example, Sufyān al-Thawrī (d. 161/777?) is quoted as saying, 'If I told you I've been relating hadith to you just as I've heard, I'd be lying.' 'Go by the first version heard' was the reported advice of Abū 'Uthmān (probably al-Nahdī, Kufan, 1. Basra, d. 95/713-14?) to 'Āṣim al-Ahwal (Basran, d. after 140/757-8) when someone complained that he would dictate a particular hadith report differently on the second occasion. ${ }^{9}$ Al-Shāfi î̀ (d. 204/820) and before him, reportedly, Mālik (d. 179/795) required that the traditionist be knowledgeable of the law, lest he overlook the significance of any change in wording and transmit wrongly. ${ }^{10}$ In other words, transmission by paraphrase (al-riwāyah bi-l-ma 'nā), although plainly too common to forbid, had to stop at changes that would entail unforeseen juridical consequences. Only expertise in jurisprudence would ensure that a transmitter made only harmless changes. ${ }^{11}$

${ }^{6}$ Two classics are Goody and Watson, "The consequences of literacy" and Ong, Orality and literacy.

${ }^{7}$ Speight, "A look at variant readings in the hadith"; Speight, "Narrative structures in the Hadith" and Speight, "Rhetorical argumentation in the hadith literature of Islam". On the long controversy over the authenticity of prophetic hadith, $v$. Motzki, The origins of Islamic jurisprudence, chap. 1, and Berg, The development of exegesis in early Islam, chap. 2. Motzki advocates what he calls the isnād-cum-matn method to identify variant wordings with particular transmitters, for which $v$. Motzki, "Dating Muslim traditions". The connection between oral transmission and drift is briefly made by, among others, Patricia Crone: "The purpose of such reports was to validate Islamic law and doctrine, not to record history in the modern sense, and since they were transmitted orally, as very short statements, they easily drifted away from their original meaning as conditions changed. (They were also easily fabricated, but this is actually less of a problem.)" So in Crone, "What do we actually know about Mohammed?". Some Muslim scholars have observed the alleged connection between drift and oral transmission and argued that, contrary to what the traditionists themselves said, writing was always crucial to the transmission of hadith, notably Nabia Abbott, Studies in Arabic literary papyri 2: Qur'anic commentary and tradition, and Sezgin, GAS, 1:53-84. But the phenomenon of drift seems massive, whether explained by oral transmission or not.

8 Ahmad ibn Hanbal, Kitāb al-'Tlal wa-ma 'rifat al-rijāl, 1:550 = Ahmad ibn Hanbal, Kitāb al-Jāmi' fì l-'ilal wa-ma 'rifat al-rijāl, 1:201 (henceforward, references to latter edn in italics).

${ }^{9}$ Abū Khaythamah, Kitāb al-'Tlm, p. 22.

10 Al-Shāfí ${ }^{\top}$, al-Risālah, 1001; Ahmad ibn Hanbal, Kitāb al- Tlal, 1:44; Ibn Abī Ḥātim, Kitāb al-Jarh wa-l-ta 'dìl, 2:32. Additional citations of Mālik in Dutton, The origins of Islamic law, pp. 17, 186.

${ }_{11}$ Described as a later compromise position between advocates of transmission verbatim and by paraphrase by Jonathan Brown, Hadith, p. 23, citing al-Khațīb al-Baghdādī, al-Jämi 'fi akhlāq al-rāwì , an edition I have not seen. $V$. also, apparently at greater length, 
However, the possibility of reshaping is not cited by advocates of purely oral transmission, rather (apart from not allowing anything to threaten the status of the Qur'ān as al-kitāb) control over who should gain access to it. For example, here is the Syrian jurisprudent al-Awzā ${ }^{\top} \overline{1}$ (d. 157/773-4?) against writing:

This matter was once clear, splendid, and noble. They used to remind one another of it (yatalāqawnahū baynahum). When it went into books, its light disappeared and it reached unqualified persons (dhahaba nūruhū wa-șāra ilà ghayr ahlihi). ${ }^{12}$

For al-Awzā $\bar{i}$, purely oral hadith transmission was attractive above all because it was exclusive. But al-Awzāè was also quoted more favourably to written notes; for example, saying that hadith from books that had been handed on but not orally dictated were not to be passed on by dictation but were good enough to guide practice, or recommending the books of his disciple al-Walid ibn Mazyad [d. 203/818-19?] as the soundest record of his own teaching..$^{13} \mathrm{He}$ is also said to have been less reliable than a certain Basran in transmitting hadith from a certain Yemeni because his notebooks had been lost. ${ }^{14}$

Secondarily, it was sometimes held that memory was more reliable than written notes. A minor Kufan traditionist is said to have sent his son to ask al-Sha ${ }^{\circ} \overline{1}$ (d. after 100/718) what to do about some notes (a șahiffah) in what he recognized as his own handwriting, sealed by what he recognized as his own signet: might he testify to what was in them? 'Only if you remember it', said al-Sha 'bī. 'People write what they please and seal what they please.' ${ }^{15}$ Similarly, Mālik is said to have ruled out accepting something from a thoroughly trustworthy man who saw an addition he did not recognize in his notebook (kitāb) ${ }^{16}$ There was presumably some chance that one had once knowingly written down something worthless.

al-Khațīb al-Baghdādī, al-Kifâyah fì 'ilm al-riwāyah, ed. Muḥammad Ḥāfị al-Tījānī, 'Abd al-Ḥalìm Muḥammad 'Abd al-Ḥalīm and 'Abd al-Raḥmān Ḥasan Mạ̣mūd, pp. 265-317 = ed. Aḥmad 'Umar Hāshim, pp. 205-247, with many more examples; also al-Rāmahurmuzì, al-Muhaddith al-făsil, pp. 533-543.

${ }^{12}$ Abū Zur'ah al-Dimashqī, al-Tārìkh, 1:364. A slightly different version apud al-Khațīb al-Baghdādī, Taqyìd al-'ilm, p. 64, cited by Cook, "The opponents of the writing," p. 471.

${ }_{13}$ Abū Zur'ah al-Dimashqī, al-Tārīkh, 1:264, 2:723; Ibn Abī Ḥātim, Kitāb al-Jarh, 1:205; Ibn Hajar, Kitāb Tahdhīb al-Tahdhīb, 11:150-1. Cf. Judd, Religious scholars and the Umayyads, p. 74, who interprets passages in Abū Zur'ah differently.

${ }^{14}$ Ibn Abī Hāāim, Kitāb al-Jarh, 9:61.

${ }_{15}$ Abū Nu aym, Hilyah al-awliyā', 4:314.

16 Ibn Abī Ḥātim, Kitāb al-Jarḥ, 2:32. 
Sahiffah and kitāb are the two words that have come up here for written records, along with the plural of the latter, kutub. With eighth-century references, from the period when writing hadith was controversial, we should normally envision notebooks, contents arranged by order of reception. Deliberately-arranged books in the modern sense, meant to be published in multiple identical copies, became common only in the ninth century. As a transitional stage, some early books were published in multiple redactions; e.g. the Muwațta ' of Mālik. ${ }^{17}$ In general, publication in multiple identical copies seems to have prevailed sooner in the field of adab, meaning roughly belles-lettres, than hadith. ${ }^{18}$

At first, writing was grudgingly accepted as a private, ancillary activity, not allowed in public. Students would hear dictation in the mosque, then write down at home what they had heard to help them remember it. For example, 'Alqamah ibn Qays (Kufan, d. after 60/67980 ?) thought writing reprehensible (makrūh) but accepted it from Masrūq ibn al-Ajda (Kufan, d. 63/682-3?) if he should erase it after memorization. ${ }^{19}$ In time, though, it became accepted in the mosque as well. ${ }^{20}$ The last experts of whom we hear strong opposition to all writing were men who died in the early ninth century. The transition is captured by Ahmad ibn Hanbal's reminiscence of sitting by the blind side of Sufyān ibn 'Uyaynah (d. 198/814), a Kufan who had transferred to Mecca, so that he would not notice that he was taking notes, which he forbade other auditors to do if he noticed it. ${ }^{21}$ At that, there are also stories indicating that Sufyān, too, used written notes; for example, the Meccan 'Amr ibn Dīnār (d. 126/743-4) is said to have reproached him on hearing that he wrote hadith: 'When I was your age, I memorized hadith.'22

${ }^{17}$ Brockopp, "Rereading the history of early Mālikī jurisprudence," esp. p. 235, and Dutton, The origins of Islamic law, pp. 22-26.

${ }_{18}$ Schoeler, The oral and the written, pp. 34-35. For positive enthusiasm for books from devotees of $a d a b, v$., for example, Günther, "Praise to the book! Al-Jāhiz and Ibn Qutaybah on the excellence of the written word in medieval Islam".

19 Ahmad ibn Hanbal, Kitāb al-'Tlal, 1:216 1:97; similarly Abū l-Hasan al-'Ijlī, Tārìkh al-thiqāt, arranged Ibn Ḥajar al-Haythamī, additions by Ibn Ḥajar al- 'Asqalānī, ed. 'Abd al-Mu'tị Qal'ajīi, p. 340.

20 Although I doubt the implications of her evidence for the authenticity of hadith going back to the Prophet, Nabia Abbott (Studies in Arabic literary papyri 2) deserves credit for her original exposition of how oral and written hadith transmission were actually combined in the ninth century.

${ }^{21}$ Ahmad ibn Hanbal, Kitāb al-'Tlal, 3:383 2:235; cited by Cook, "The opponents of the writing," p. 468.

22 Abū l-Qāsim al-Baghawī, al-Ja 'dìyāt, 1:483. 
Ahmad ibn Hanbal (d. 241/855) was one of the most prominent hadith collectors and critics of the ninth century. ${ }^{23} \mathrm{He}$ himself strongly advocated the use of written notes. He forbade his son 'Abd Allāh and his Basran contemporary 'Alī ibn al-Madīnī (d. 234/849) to relate hadith without their notebooks at hand. He almost never related hadith himself without a notebook in his hand. ${ }^{24}$ He told Ibn Hāni' (d. 275/888-9) that he preferred him to read out a hadith report from his notebook as both looked at the book, rather than just letting the student listen to Ahmad read it aloud. ${ }^{25}$ But even he said that someone who relied on written transmission alone always distorted (yusahhifu) ${ }^{26}$ And notice that the form of oral transmission was maintained: he did not just lend Ibn Hāni' his notebook to copy from. It was at about the turn of the ninth century when haddathani and akhbarani, which expressly pointed to direct oral transmission, replaced unspecific 'an in reported chains of transmission (asānìd). Here is a chart showing the rise and fall of different terms for transmission among different generations of traditionists in Bukhārī's Sahị̄h (percentages of a sample of 238):

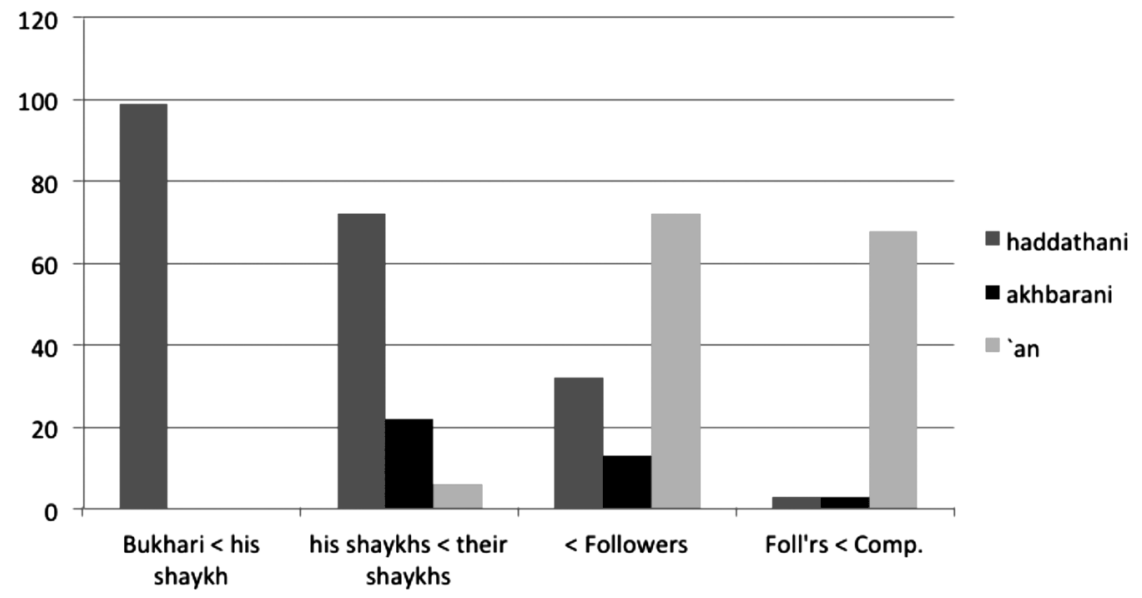

${ }^{23}$ Bashīr 'Alī 'Umar, Manhaj al-imām Ahmad fì i'lāl al-hadìth; Abū Bakr ibn Laṭîf Kāfì, Manhaj al-imām Ahmad fì l-ta' 'Tll, and Melchert, Ahmad ibn Hanbal, chap. 2.

${ }^{24}$ Ibn 'Asākir, Tārīkh madīnat Dimashq, 5:279-80.

${ }^{25}$ Ibn Hāni', Masā'il al-imām Ahmad, 2:224.

${ }^{26}$ Ibn Hāni', Masā' 'il, 2:225. 
That is, it was just when writing was coming to be universally accepted, in the late eighth century, that the overwhelming majority of transmitters evidently took it to be important to specify that transmission had been direct and oral.

Some instances of destroying books have been noted by Franz Rosenthal and Michael Cook. On his deathbed, 'Abìdah al-Salmānī (Kufan, d. 72/691-2?) had his books erased, saying 'I fear that someone after me should get them and put them where they do not belong. ${ }^{27}$ Abū Qilābah (Basran, d. 105/723-4?) bequeathed his books to Ayyūb al-Sakhtiyānī (Basran, d. 131/748-9?) with instructions otherwise to burn them. ${ }^{28}$ Al-Hasan al-Bașin (d. 110/728) had a servant burn his books (sahịfahs) ${ }^{29}$ Shu'bah (Basran, d. 160/776) ordered that his books be washed on his death, which his son saw to. ${ }^{30}$ Sufyān al-Thawrī transferred his books to 'Ammār ibn Sayf(Kufan) with instructions to bury them when he died. ${ }^{31}$

I have come across some others. The Companion Ibn Mas' $\bar{u} d(d$. 32/652-3?) had a sahifah containing hadith washed, then burnt. ${ }^{32}$ The Companion Abū Mūsā al-Ash arī (d. 50/670-1?) washed the ink from

${ }^{27}$ Ibn Sa'd, Biographien, 6:63 = al-Tabaqāt al-kubrā, 6:94 (henceforward, references to latter edn in italics); cited by Cook, "The opponents of the writing," p. 480, with additional references. Cook offers the translation, 'I'm afraid that someone may get possession of them when I'm dead and misconstrue them.' I suppose that the issue is who has access to them; that is, someone dependably orthodox or not. 'He called for his books to be burnt or erased' according to Ahmad ibn Ḥanbal, Kitāb al-'Tlal, 1:215 1:97.

${ }^{28} \mathrm{Ibn}$ Sa ${ }^{\circ}$, Biographien, 7/1:135 7:185; cited by Cook, "The opponents of the writing," p. 481.

${ }_{29}$ Ibn Sa'd, Biographien, 7/1:127 7:174-5; cited by Cook, "The opponents of the writing," p. 481.

${ }_{30}$ Al-Khatịib al-Baghdādī, Taqyìd al-'ilm, p. 62; cited by Cook, "The opponents of the writing," p. 481.

31 Ibn Sa"d, Biographien, 6:271 6:388; cited by Rosenthal, "“Of making many books there is no end"', p. 41, and Cook, "The opponents of the writing," p. 481. An early Hanbali source mentions that some were burnt, some washed and resold (as blank sheets), and some buried: Harb al-Kirmānī, Masā'il al-imām Aḥmad ibn Muhammad ibn Hanbal wa-Ishāa ibn Rāhawayh, p. 494. An Abū 'Abd al-Raḥmān al-Hārithī is remembered as having retrieved from burial by Sufyān himself a notebook from which Sufyān had related hadith to him personally: Abū Nu aym, Hilyah, 7:64.

${ }^{32}$ Ibn Abī Shaybah, al-Mușannaf, Kitāb al-adab 149, fì ị̆rāq al-kutub wa-mahwihā $=$ ed. al-Luhaydān, 8:552. This section includes four reports, one of 'Abīdah's destroying his books, two apparently concerning letters. Muslim ibn Yasār (Basran, d. 101/719-20?) would erase the name of God before throwing away a letter (loc. cit.). Here, the issue seems to be the respectful treatment of the sacred name. Similarly 'Abd al-Razzāq's section on the burning of books has Ṭāwūs (Yemeni, d. 106/ 725?) burn letters in which the basmalah was written, whereas Ibrähìm al-Nakha 1 (Kufan, d. 96/714?) disapproves of burning writing that mentions God: 'Abd al-Razzāq, al-Mușannaf, 11:425. 
a book his son had written of his talk. ${ }^{33}$ The Companion 'Imrān ibn Huṣayn (d. Basra, 52/672) erased something that Humayd ibn Hilāl (Basran Follower) had written of his hadith, saying 'Memorize as I memorized.' 34 'Urwah ibn al-Zubayr (d. 94/712-13?) burned some books of his containing fiqh (law) on the Day of al-Harrah (26 Dhū al-Hijjah 63/26 August 682), when the Medinese repulsed an expedition from Syria near the start of the Second Civil War. ${ }^{35}$ 'Alī ibn Mus'hir (Kufan, d. 189/804-5) buried his books after going blind; i.e. at the point at which they no longer served to keep the hadith there in his own memory. ${ }^{36}$ Muhammad ibn Aslam (d. Nishapur, 242/856) ordered his books to be buried on his death. ${ }^{37}$ Ibn Abì Hâtim ordered the notes of his father, Abū Hātim al-Rāzī (d. 277/890), and Abū Zur'ah al-Rāzī (d. 264/878) to be buried. ${ }^{38}$ Ibn al-Jie ābī (Baghdadi, d. 355/965) ordered his books to be burnt on his death. ${ }^{39}$ The Companion stories just mentioned seem intended to document the undesirability of writing hadith. In all the other cases, the point would have been to prevent persons from relating hadith from these notebooks as if they had directly, physically heard them from their collectors. They might have misinterpreted the handwriting. Possibly, they contained dubious hadith reports that their compilers would not have repeated to anyone. Numbers of quotations indicate distress among traditionists at the thought that false hadith should be published on their authority; for example, from Shu 'bah, 'By God, I am safer with regard to poetry than I am with regard to hadith' and 'I am worried about nothing else that I fear might put me into the Fire', meaning hadith. ${ }^{40}$

33 Ahmad ibn Hanbal, Kitāb al- 'Tlal, 1:214 1:96.

${ }^{34}$ Abū Zur'ah al-Dimashqī, al-Tārìkh, 1:555.

${ }^{35}$ Ibn Sa'd, Biographien, 5:133 5:179. 'Urwah is also quoted as saying, 'We used to say, "Let us take up no book besides the Book of God," so I erased my books. By God, I wish that I had my books. The Book of God has steadfastly endured' (Abū Nu'aym, Hilyah, $2: 176)$. Unlike Ibn Sa'd's report, this one plainly has to do with allaying fears that writing hadith would threaten the Qur'ān.

${ }^{36}$ Ibn Numayr, apud Yahyāa ibn Ma 'īn, al-Tārìkh, recension of 'Abbās al-Dūrī, ed. Aḥmad Muhammad Nūr Sayf, 2:423.

$37 \mathrm{Abū} \mathrm{Nu}$ aym, Hilyah, 9:241.

38 Al-Khalīi î, al-Irshād, abr. al-Silafî, ed. 'Āmir Ahmad Haydar, p. 229, s.n. Abū Muhammad 'Abd al-Raḥmān ibn Abī Hātim al-Rāzī.

${ }^{39}$ Muhammad ibn 'Abd Allāh al-Musabbihịi, apud al-Dhahabī, Tārìkh al-istām, 26 (351-380 H.): 128.

${ }^{40}$ Ibn Sa'd, Biographien, 7/2:38 7:280-1. On the riskiness of poetry, consider the 
Sometimes, one speculates that the burying of books was posited to explain someone's weakness. Mu'ammal ibn Ismāênl (Basran, d. Mecca, 206/822) was said by someone to have buried his books, then tried to relate hadith by memory and made mistakes. But there are many other reports of his weakness that do not mention the burial of books, only his making many mistakes and imagining things. ${ }^{41}$ This would be comparable to the case of Ibn Lahīah (Egyptian, d. 174/790?), discussed by Eerik Dickinson. Different reports indicate that Ibn Lahī ah became unreliable after he lost his books to a fire, after he became senile, after he suffered a stroke; alternatively, that he himself was careless or that some but not all of his students were careless. ${ }^{42}$ Altogether, it seems plain that traditionists knew certainly that Ibn Lahi ${ }^{-}$ah was associated with some hadith reports they accepted and with others they rejected, and that reports of burnt books, senility, stroke, and so on were simply guesses as to why.

Sometimes, books were expressly said to have been destroyed because they contained misattributed hadith reports. Ahmad ibn Hanbal told someone to leave or burn a collection of questions from Khālid ibn Abī 'Imrān (African $q \bar{a} d \bar{l}$, d. 129/746-7?) to the prominent Followers al-Qāsim and Sālim falsely attributed to al-Zuhrī (Medinese, d. 124/741-2?). ${ }^{43}$ Ibn Sa d reports Sufyān al-Thawrī's command that his books be buried without explanation. By another account, however, Sufyān had regretted some things that he had written from some persons, saying, 'I was led to it by lust for hadith (shahwat al-hadìth). ${ }^{\text {44 }}$ This touches on renunciant distrust of the culture of hadith. Yahyā ibn Ma īn (d. 233/848) burnt what he had written down from Khālid ibn

widely-reported dictum of the Prophet, 'It would be better for one of you for his interior to be filled with pus than that it be filled with poetry': Bukhārì, Șahìh, Kitāa al-adab 92, bāb mā yukrahu an yakūna al-ghālib 'alā al-insān al-shi'r, nos 6154-5; Muslim, Jāmi', Kitāb al-shi 'r 7-9, nos 2257-8; Abū Dāwūd, Sunan, Kitāb al-adab 87, bāb mā jā 'a fì l-shi 'r, no 5009; Tirmidhī, Jāmi ', Abwāb al-adab 105, bāb mā jā' 'a la 'an yamtali' a jawf ahadikum shi 'ran, nos 2851-2; Ibn Mājah, Sunan, Kitāb al-adab 42, mā kuriha min al-shi' r, nos 3759-60; Ahmad ibn Hanbal, Musnad 1:175, 177, 181, 2:188, 331, 355, 391, 478, $480=$ ed. Arna'ūṭ, 3:95-6, 116, 139, 13:258-9, 14:109, 294, 15:42, 16:153-4, 164; Ibn Abī Shaybah, al-Musannaf, 8:512-14.

${ }^{41}$ Ibn Hajar, Kitāb al-Tahdhīb, 10:381.

42 Dickinson, The development of early Sunnite hadith criticism, pp. 99-101, 124-125.

43 Ahmad ibn Hanbal, Kitāb al-'Tlal, 2:56-7 1:224.

${ }_{44} \mathrm{~A} \dot{\mathrm{bu}} \mathrm{Nu}$ aym, Hilyah, 7:64 ; alternatively, shuhrat al-hadìth, 'the fame of hadith', at 7:38, meaning the prospect of achieving it. 
al-Qāsim al-Madāyinī (d. 211/826-7), whom others accused of being weak or becoming senile. ${ }^{45}$

Renunciants $(z u h h \bar{a} d)$ apparently destroyed notebooks either because hadith transmission tended to make them self-important or lest hadith study distract them from recollecting God. ${ }^{46}$ Al-Hasan ibn Rūdabār (Kufan, d. late 2nd/early 8th cent.) buried his books, saying it was not suitable to spend all one's life on hadith. ${ }^{47} \mathrm{Abu}$ ' Amr ibn al- 'Alā' (Basran, d. Kufa, 154/770-1?), one of the famous seven readers of the Qur'ān, burnt his books when he devoted himself entirely to worship. ${ }^{48}$ Dāwūd al-Ṭā'ì (Kufan, d. 165/781-2) sat with Abū Hanīfah till he acquired a reputation for talking much, then grew silent and later threw his books into the Tigris, after which he devoted himself to worship and withdrew from society. ${ }^{49}$ The story is told that Abū Usāmah Hammād ibn Usāmah (Kufan, d. 201/817) objected to Ibn al-Mubārak that the previous generation had not sorted hadith by topic and put together written collections, provoking Ibn al-Mubārak to abstain from dictating hadith for about 20 days. When he was observed dictating again to a circle of auditors, Ibn al-Mubārak lamely told him, similarly to Sufyān, 'lust for hadith (shahwat al-hadìth)'. ${ }^{50}$ Yūsuf ibn Asbāt (d. 195/810-

${ }^{45}$ Ibn Hajar, Lisān al-Mīzān, 2:384.

46 Some of the following examples were also brought up in an earlier article by me, "Early renunciants as hadith transmitters," p. 413, where fuller explanations of renunciant distrust are offered. This is to disagree with Rosenthal ("Of making many books," p. 43), who explains renunciant hostility to books by "the pietistic/mystic attitude and the long tradition of philosophers (such as Socrates) and, above all, mystics who feel revulsion at the thought of profaning their insights'. The books in question here comprise hadith, not mystical thought, and such explicit derogations of collecting hadith as I have come across show no concern for profaning mystical insight.

${ }^{47}$ Abū l-Hasan al-' 'Ijlì, Tārīkh al-thiqāt, p. 114.

48 Al-Jāhiziz, al-Bayān wa-l-tabyìn, 1:321; Ibn al-Jazarī, Ghāyat al-nihāyah fi țabaqāt al-qurrā', 1:290. Cook, citing al-Jāhiz, says 'the stated motive is that he turned to Koranic recitation (taqarra'a)': Cook, "The opponents of the writing," p. $495 \mathrm{fn}$. However, this verb was also commonly used in the sense of becoming a qäri', meaning a renunciant; e.g Abū Nu'aym, Hilyah, 6:290, where Abū 1-Tayyāh (Basran, d. 128/745-6) associates it especially with fasting. This sense is confirmed by Ibn al-Jazarì, who quotes the Basran grammarian Abū 'Ubaydah (d. ca. 210/825-6) as describing how Abū 'Amr's notebooks (dafâtir) filled a house to the ceiling, 'then he became a renunciant (tanassaka), so he burnt them and devoted himself solely to worship.'

49 Abū Nu'aym, Hilyah, 7:336. But other stories of his becoming silent and withdrawing from society do not mention the destruction of his books (notably at Hilyah 7:342), so this was not an essential detail.

${ }^{50}$ Abū Nu'aym, Hilyah, 8:165. On Abū Usāmah's destruction of notebooks v. infra. 
11) buried his books near Wasit where the flood would later destroy them. He explained, 'I wanted my concern to be one. ${ }^{51} \mathrm{He}$ also reportedly associated hadith transmission with conceitedness, as in telling a man he saw with a daftar (notebook) in his hand, 'You ornament yourselves as you like, but God will not give you more of anything but lowliness. ${ }^{52} \mathrm{He}$ later related hadith from memory, but, without his notebooks, it did not come out as it was supposed to. ${ }^{53}$ 'Ațâ' ibn Muslim al-Khaffāf (Kufan, moved to Aleppo, d. 190/806) was a pious man (ṣallih) likened to Yūsuf ibn Asbāt. He buried his books, then related hadith from memory and imagined things. ${ }^{54}$ Muhammad ibn Yūsuf(Isfahani, d. ca. 200/815-16) buried his books, saying, 'Grant you were a judge — so what (fa-kāna mādha $)$ ? Grant you were a mufti-so what? Grant you were a traditionist-so what? ${ }^{55} \mathrm{He}$ is also quoted as expressly warning against the tendency of hadith transmission to make one conceited: 'Relate hadith to the people and teach them, but when people gather around you, observe how your heart is. ${ }^{56}$

Abū Usāmah buried his books, then later borrowed others' books and illicitly transmitted what he had copied from them. ${ }^{57} \mathrm{I}$ have found no explanation for his burying those books, but he had a reputation for being a renunciant ( $k \bar{a} n a$ yu 'addu min al-nussāk), so it was presumably from pious humility. ${ }^{58}$ Bishr al-Hāāî (d. Baghdad, 227/841) had eighteen containers of his books buried. ${ }^{59}$ Salm ibn Maymūn al-Khawwās (fl. early 3rd cent.) was a worshipper who buried his books, then related hadith from memory, on which account he was accused of making mis-

51 Al-'Uqaylī, Kitāb al-Du'afă' al-kabìr, 4:454.

${ }^{52}$ Abū Nu'aym, Hilyah, 10:170.

${ }^{53}$ Al-Bukhārī, al-Târìkh al-kabìr, 8:385; cited by Cook, "The opponents of the writing," p. 481.

${ }_{54}$ Ibn Abī Ḥātim, Kitāb al-Jarh, 6:336; cited by Cook, "The opponents of the writing," p. 481.

${ }^{55}$ Abū Nu'aym, Hilyah, 8:227.

${ }^{56} \mathrm{Abū} \mathrm{Nu}$ aym, Hilyah, 8:234-5.

57 Ahmmad ibn Hanbal, Kitāa al-'Tlal, 3:209 2:161. Other references to his burying his books apud Ibn Ḥajar, Kitāb Tahdhìb, 2:3. Despite his practice, Abū Usāmah appears in all of the Six Books.

${ }^{58}$ Ibn 'Ammār, apud Ibn Hajar, Kitāb Tahdhīb, 2:3. This Ibn 'Ammār may have been the preacher Manșūr (d. Baghdad, early 200s/ca. 820?), on whom v. Dhahabī, Tārīkh, 13 (191-200 H.): 409-14, with further references.

${ }_{59}$ Al-Khațīb al-Baghdādī, Tārìkh Baghdād, 7:71 = Al-Khațīb al-Baghdādī, Tārìkh Madinat al-Saīàm, 7:551. 
takes. ${ }^{60} \mathrm{Abu}$ Nu aym quotes two stories from al-Sulamī and adds a third from another source describing how the Syrian Ibn Abī l-Hawārī (d. 246/860) cast his books into the Tigris. A representative example quotes him as saying, 'What a good guide you were; but pre-occupation with the guide after one has arrived is preposterous (muhāl). ${ }^{\prime 61}$ Muhammad ibn Mu ādh (d. 334/945-6) said he was 120 years old and had heard hadith from Abū 1-Walīd al-Ṭayālisī (d. 224/838-9) and others, then become a Sufi and buried his books. He consequently forgot all but one of his old hadith reports before resuming his collection. ${ }^{62}$ His biographers reasonably doubt whether he was really that old, but it seems significant that becoming a Sufi was taken to be a plausible reason for someone to have buried his books.

The most famous example of destroying books on account of renunciant concerns is that of Abū Hayyān al-Tawhīdī (fl. late 4th/10th cent.), who was blamed for burning his. ${ }^{63} \mathrm{He}$ adduced in his own defence the examples of $A b \bar{u}$ 'Amr ibn al-'Alā', who buried his books, Dāwūd al-Ṭā' $\overline{1}$, who threw his into the sea (i.e. river), Yūsuf ibn Asbāt, who threw them into a cave that he then blocked up, Abū Sulaymān al-Dārānī, who burnt his, and Sufyān al-Thawrī, who tore up a thousand fascicles and threw them to the wind. ${ }^{64}$ The one of these for which I have not found an independent report is Abū Sulaymān al-Dārānī (Syrian, d. 215/830-1?). However, what Abū Hayyān al-Tawhīìi quotes Abū Sulaymān as saying to his books is a slightly more elaborate version of what his younger contemporaries al-Sulamī (d. Nishapur, 412/1021) and Abū Nu 'aym al-Ișbahānī (d. Isfahan, 430/1038) attribute to Abū Sulaymān's disciple Ibn Abī l-Hawārī (quoted above). Both Abū Sulaymān and Ibn Abī l-Hawārī had reputations for transmitting hadith, although Ibn Abī l-Hawārî̀'s was greater (e.g. his name appears in two

${ }^{60}$ Ibn Abī Hātim, Kitāo al-Jarh, 4:267.

${ }^{61}$ Abū Nu aym, Hilyah 10:6-7 (Muhammad ibn al-Husayn ibn Mūsā is al-Sulamī). Two quotations, including the one here translated, are also expressly attributed to al-Sulami, Tārìkh al-șüfiyah by al-Dhahabī, Tärīkh, 18 (241-250 H.): 54-5.

${ }^{62}$ Ibn Ḥajar, Lisān, 5:385, citing Ibn 'Asākir, Tārīkh, s.n. 'Abd al- 'Azīz ibn Muhammad al-Yahsubī, but I have not found such a biography in Tārīkh Madīnat Dimashq itself.

${ }^{63}$ Reviewed by Rosenthal, "Of making many books," p. 40; at greater length by Wadād al-Qādịi, "Scholars and their books: a peculiar view from the fifth/eleventh century".

${ }^{64}$ Yāqūt, Irshād al-arīb, ed. Margoliouth, 5:389 = ed. Iḥsān 'Abbās, 5:1931; trans. by al-Qāḍī, "Scholars," pp. 638-639. 
of the Six Books).$^{65}$ The multiplicity of quotations suggests elaboration over time; so does their mystical tinge. Neither attribution, then, seems certain. On balance, however, I tend to favour Ibn Abī l-Hawārī as the one who destroyed his books.

At least once, a book was destroyed from sheer malice. Hushaym ibn Bashïr (d. Baghdad, 183/799) lent his book (sahïfah) of hadith from al-Zuhri to Shu bah, who threw it into the Tigris from envy ${ }^{66}$ Destruction of books in hadith circles for the sake of suppressing wrong ideas is reported only rarely. Nu aym ibn Hammād (d. Baghdad, 228/843?) paid fifty dinars for some books from Ibrāhīm ibn Muhammad ibn Abì Yahyā (d. al-Ḥadath, 191/806-7?), a traditionist of mixed reputation sometimes cited by al-Shāfi ${ }^{\top} \overline{1}$, then tore them up when some turned out to report Qadarī and Jahmī positions. ${ }^{67}$ Ahmad ibn Hanbal recommended that if someone dies leaving many books of $r a^{\prime} y$ (meaning jurisprudence not founded on Qur'ān and hadith), they should be buried, even though he have debts (which would make it tempting to sell them). ${ }^{68}$ Otherwise, he commanded that wrong passages be struck out, such as hadith from unqualified persons, misrepresentations of his own opinions, or hadith falsely said to have been related by him. ${ }^{69}$

Striking out particular hadith is mentioned much more often than destroying whole books. In Ahmad's own books, it was observed that he had struck out hadith from 'Alī ibn al-Ja ${ }^{\circledR}$, Sa ${ }^{e} \overline{1} d$ ibn Sulaymān, 'Alī ibn al-Madinī, and others who had answered as bidden at the Inquisition. ${ }^{70}$ Ibrāhīm ibn Ṭahmān (Khurasani, d. Mecca, 163/779-80?) is quoted as having written to the people of Nishapur commanding them

65 For Abū Sulaymān al-Dārānī, v. al-Dhahabī, Tārīkh, 15 (211-220 H.): 252-5; for Ibn Abī 1-Hawārī, al-Dhahabī, Tārìkh, 18 (241-250 H.): 51-5, both with further references.

66 Khalīìi, al-Irshāe, p. 19.

${ }^{67}$ Ibn Hajar, Kitāb al-Tahdhīb, 1:158-9, apparently quoting 'Abbās al-Dūrī < Yahyā ibn Ma ${ }^{\top} \bar{i}$, but I have not traced the quotation in his Tärìkh.

68 Ibn Abī Ya'lā, Tabaqāt al-hanāabilah, 1:347, s.n. Muhannā ibn Yahyā. The printed text refers to kutub al-rāzi , which I take to need correction, confirmed by the version in al- 'Ulaymī, al-Manhaj al-ahmad fì tarājim aṣhāab al-imām Ahmad, 2:163.

${ }^{69}$ For hadith from unqualified persons (qawm lā yasta'hilūna an yuhaddatha 'anhum), v. Șālih ibn Ahmad, Masā'il al-imām Ahmad ibn Hanbal, no 518. For misrepresentations of Ahmad's opinions, v. al-Khallāl, al-Sunnah, ed. 'Ațiyah ibn 'Ațīq al-Zahrānī, 7:95-100 = ed. Abū 'A Aṣim al-Hasan ibn 'Abbās ibn Quṭ, 2:335-8. For someone who said he had related hadith of Ahmmad, v. Aḥmad ibn Hanbal, Kitāb al-'Ilal, 1:34, also apud Ibn Hajar, Kitāb al-Tahdhīb, 11:244, s.n. Yahyā ibn 'Abd al-Hamīd al-Himmānī.

70 Abū Zur 'ah al-Rāzì, Kitāb al-Ḍu 'afà', 3:546-7; al- 'Uqaylì, Kitāa al-Ḍu 'afā', 3:239. 
to erase whatever they had written down of his transmission from Abū Hanīfah. ${ }^{71}$ Ibn al-Mubārak (Khurasani, d. Hit, 181/797) is said to have struck out the hadith of Abū Hanifah (in his own notes) a few days before he died. ${ }^{72}$ 'İsā ibn Yūnus (d. al-Hadath, 191/806?) told traditionists to strike out hadith in their notebooks from Ismāè 1 ibn 'Ayyāsh and Ibrāhīm ibn Abī Yahyāa ${ }^{73}$ Someone noticed that 'Abd al-Raḥmān ibn Mahdi (d. Basra, 198/814) had struck out some hadith in a notebook of his. On being asked, 'Abd al-Raḥmān explained, 'Yahyāa (ibn Sa'īd al-Qattān) informed me that he was accused of holding the opinion of Jahm (ibn Șafwān, that the Qur'ān was create), so I struck out his hadith. ${ }^{74}$ Abū Hāâtim al-Rāzī commanded that hadith from 'Alī ibn Abì Hāshim (Baghdadi, d. 220s/835-45?) be struck out because he had refused to take a position on the creation of the Qur'ān. ${ }^{75}$

There are probably two reasons why traditionists seldom burnt books. First, books were expensive, so that books with wrong ideas would have seldom come into their possession. Secondly, theirs was still largely an oral culture, albeit dependent on private notebooks. This is why, when Harūn al-Rashīd ( $r$. 170-93/786-809) tried to suppress what he considered unorthodoxy, he did not have books burned, rather forbade the unorthodox offender to lecture. ${ }^{76}$ As for the traditionists, they aimed to suppress wrong ideas mainly by not talking about them. 'They left his hadith' is a common expression of rejection; for example, what Abū Hạtim al-Rāzì did to hadith he had heard from al-Bukhārī after he received a letter charging him with an unorthodox opinion about the pronunciation of the Qur'ān. ${ }^{77}$ Sometimes it was applied to persons; e.g. the feckless Ibrāhīm ibn Abī Yahyā mentioned above, of whom the critics al-Bukhārī said 'disreputable of hadith (munkar al-ha-

71 Ibn Hibbān, Kitāb al-Majrūhīn, 3:71.

72 Ahmad ibn Hanbal, Kitāb al-'Ilal, 3:269 2:187

73 Ibn Hibbān, Kitāb al-Majrūhīn, 1:107. Ismāēil ibn 'Ayyāsh was a Homsi (d. 181/797-8?) accused of inaccuracy, especially in what he related of Hijazis and Iraqis (summary in Ibn Hajar, Kitāb al-Tahdhīb, 1:321-6). 'Ibrāhīm ibn Abī Yahyā' seems to indicate Ibrāhīm ibn Abī Hayyah, a Meccan ( $f l$. later $2^{\text {nd }} / 8^{\text {th }}$ cent.) roundly accused of inventing hadith (v. Ibn Hajar, Lisān, 1:52-3, 124).

74 Abū Nư aym, Hilyah, 9:6.

75 Ibn Abī Hātim, Kitāb al-Jarh, 6:195.

76 So with regard to the Basran Ismāêl ibn 'Ulayyah (d. 193/808-9) for saying the Qur'ān was create, according to Ibn Hāni', Masā'il, 2:160, and Șālih ibn Aḥmad, Sìrat al-imām Ahmad ibn Hanbal, p. 67.

77 Ibn Abī Hātim, Kitāb al-Jarh, 7:191. 
dìth)', al-Nasā'i 'weak', and al-Dāraquțnī simply 'left (matrūk)'. ${ }^{78}$ They would strike out names and hadith reports in notebooks to keep themselves from repeating them to others. As Sufyān al-Thawrī was quoted as saying, 'Whoever hears an innovation, let him not take any of it to those with whom he sits, not casting it into their hearts. ${ }^{79}$

\section{Sources and bibliography}

\section{Sources}

'Abd al-Razzāq, al-Muṣannaf, Ḥabīb al-Raḥmān al-A ẓamī (ed.), Johannesburg, Majlis Ilmi, 1390-2/1970-2, Min Manshūrāt al-Majlis al- 'Ilmī 39, 11 vols.

Abū l-Ḥasan al- 'Ijlī, Tārīkh al-thiqāt, 'Abd al-Mu ț̣i Qal 'ajī (ed.), Beirut, Dār al-Kutub al-'Ilmīyah, 1405/1984.

Abū Khaythamah, Kitāb al- 'Tlm, Muḥammad Nāṣir al-Dīn al-Albānī (ed.), Beirut, al-Maktab al-Islāmī, 1403/1983.

Abū Nu'aym, Hilyat al-awliyā', Cairo, Maṭba'at al-Sa'ādah and Maktabat al-Khānjī, 1352-7/1932-8, 10 vols.

Abū l-Qāsim al-Baghawī, al-Ja dìyāt, Rif at Fawzī 'Abd al-Muțalib (ed.), Cairo, Maktabat al-Khānjī, 1415/1994, 2 vols.

Abū Zur'ah al-Dimashqī, al-Tārīkh, Shukr Allāh Ni mat Allāh al-Qawjānī (ed.), Damascus, Majma' al-Lughah al-'Arabìyah, 1980, 2 vols.

Abū Zur'ah al-Rāzī, Kitāb al-Ḍu'afà', Sa dì al-Hāshimī (ed.), in Abū Zur'ah al-Rāzì wa-juhūduhu fì l-sunnah al-nabawìyah, al-Manșūrah, Dār al-Wafā' and Medina, Maktabat Ibn al-Qayyim, 1409/1989, 3 vols. $2^{\text {nd }}$ ed.

Aḥmad ibn Hanbal, Kitāb al-'Tlal wa-ma 'rifat al-rijāl, Waṣī Allāh ibn Muhammad 'Abbās (ed.), Beirut, al-Maktab al-Islāmī, 1988, 4 vols.

Aḥmad ibn Hanbal, Kitāb al-Jāmi' fi l-'ilal wa-ma 'rifat al-rijāl, Muhammad Ḥusām Bayḍūn (ed.), Beirut, Mu’assasat al-Kutub al-Thaqāfiyah, 1410/1990, 2 vols.

Aḥmad ibn Hanbal, Musnad al-imām, Shu ayb al-Arna'ūt et al. (ed.), Beirut, Mu'assasat al-Risālah, 1413-21/1993-2001, 50 vols.

Aḥmad ibn Hanbal, Musnad imām al-muhaddithīn, Cairo, al-Maṭba ah al-Maymaniyah, 1313/1895, 6 vols.

al-Bukhārī, al-Tārīkh al-kabìr, Hyderabad, Mațba at Dā'irat al-Ma ārif al-Niẓāmìyah, 1941-5, 4 vols. in 8; repr. Hyderabad, Maṭba at Dā'irat al-Ma ārif

78 Ibn Hajar, Lisān, 1:52.

79 Abū Nu'aym, Hilyah, 7:34. 
al- 'Uthmānīyah, 1377/1958; reprinted with index Beirut, Dār al-Kutub al- 'Ilmiyah, n.d.

al-Dhahabī, Tārīkh al-islām, 'Umar 'Abd al-Salām Tadmurī (ed.), Beirut, Dār al-Kitāb al- 'Arabī, 1407-21/1987-2000, 52 vols.

Ḥarb al-Kirmānī, Masā'il al-imām Aḥmad ibn Muhammad ibn Hanbal wa-Ishạa ibn Rāhawayh, Nāṣir ibn Su ūd ibn 'Abd Allāh al-Salāmah (ed.), Riyadh, Maktabat al-Rushd, 1425.

Ibn Abī Hātim, Kitāb al-Jarh wa-l-ta 'dīl, Hyderabad, Jam īyat Dā'irat al-Maeārif al- 'Uthmānìyah, 1360-71, 9 vols. repr. Beirut, Dār Ihyā' al-Turāth al- 'Arabī, n.d.

Ibn Abī Shaybah, al-Muṣannaf, Muhammad 'Abd Allāh al-Jum 'ah and Muhammad Ibrāhīm al-Luhaydān (ed.), Riyadh, Maktabat al-Rushd, 1425/2004, 16 vols.

Ibn Abī Ya'lā, Ṭabaqāt al-ḥanābilah, Muḥammad Ḥāmid al-Fiqī (ed.), Cairo, Matba at al-Sunnah al-Muhammadiyah, 1371/1952, 2 vols.

Ibn 'Asākir, Tārīkh madīnat Dimashq, Muhibb al-Dīn Abū Sa'īd 'Umar ibn Gharāmah al- 'Amrawī (ed.), Beirut, Dār al-Fikr, 1415/1995, 80 vols.

Ibn Hajar, Kitāb Tahdhīb al-Tahdhīb, Hyderabad, Majlis Dā'irat al-Maeārif al-Nizāmīyah, 1325-7, 12 vols; repr. Beirut, Dār Șādir, n.d.

Ibn Ḥajar, Lisān al-Mìzān, Hyderabad, Majlis Dā'irat al-Ma'ārif, 1329-31, 7 vols. repr. Beirut, Mu'assasat al-A 'lamī, 1406/1986.

Ibn Hāni', Masā'il al-imām Aḥmad, Zuhayr al-Shāwīsh (ed.), Beirut, al-Maktab al-Islāmī, 1400, 2 vols.

Ibn Hiibbān, Kitāb al-Majrūḥ̄n, Mạ̣mūd Ibrāhīm Zāyid (ed.), Aleppo, Dār al-Wa'y, 1396, 3 vols.

Ibn al-Jazarī, Ghāyat al-nihāyah fi țabaqāt al-qurrā', Gotthelf Bergsträßer (ed.), Cairo, Maktabat al-Khānjī, 1351-2/1932-3, 3 vols. repr. Baghdad, Maktabat al-Muthannā, n.d; repr. Beirut, Dār al-Kutub al- 'Ilmìyah, 1400/1980.

Ibn Numayr, al-Tārīkh, Aḥmad Muhammad Nūr Sayf (ed.), Mecca, Jāmi at al-Malik 'Abd al- 'Azīz, Markaz al-Baḥth al- 'Ilmī wa-Ihyyā' al-Turāth al-Islāmī, 1399/1979, Min al-turāth al-islāmì' 1, 2 vols.

Ibn Sa d, Biographien, Eduard Sachau et al. (ed.), Leiden, E.J. Brill, 1904-40, 9 vols. in 15.

Ibn Sa d, al-Ṭabaqāt al-kubrā, Beirut, Dār Șādir, 1957-68, 9 vols.

al-Jāḥiz, al-Bayān wa-l-tabyīn, 'Abd al-Salām Muhammad Hārūn (ed.), Cairo, Maṭba at Lajnat al-Ta'lif wa-1-Tarjamah wa-1-Nashr, 1367-9/1948-50, Maktabat al-Jāhiz, 2, 4 vols. in 2.

al-Khalīlī, al-Irshād, 'Āmir Ahmmad Ḥaydar (ed.), Mecca, al-Shāmīyah, 1993/1414.

al-Khallāl, al-Sunnah, 'Ațiyah ibn 'Ațīq al-Zahrānī (ed.), Riyadh, Dār al-Rāyah, 1994/1415, 7 vols in 3.

al-Khallāl, al-Sunnah, Abū 'Āṣim al-Ḥasan ibn 'Abbās ibn Quṭb (ed.), Cairo, al-Fārūq al-Ḥadìthah, 1428/2007, 2 vols. 
al-Khațīb al-Baghdādī, al-Kifāyah fì 'ilm al-riwāyah, Aḥmad 'Umar Hāshim (ed.), Beirut, Dār al-Kitāb al- 'Arabī, 1405/1985.

al-Khațīb al-Baghdādī, al-Kifâyah fì 'ilm al-riwāyah, Muḥammad Ḥāfiz al-Tījānī, 'Abd al-Ḥalīm Muḥammad 'Abd al-Halīm and 'Abd al-Rạ̣mān Ḥasan Mạ̣mūd (ed.), Cairo, Matba at al-Sa'ādah, 1972.

al-Khațīb al-Baghdādī, Tārīkh Baghdād, Cairo, Maktabat al-Khānjīi, 1349/1931, 14 vols.; repr. Cairo, Maktabat al-Khānjī and Beirut, Dār al-Fikr, n.d.

al-Khațīb al-Baghdādī, Taqyìd al- 'ilm, Yūsuf al- 'Ishsh (ed.), Beirut, Imprimerie Catholique, 1946; repr. n.p., Dār Ihyā̄' al-Sunnah al-Nabawìyah, n.d.

al-Khațīb al-Baghdādī, Tārīkh Madīnat al-Salām, Bashshār 'Awwād Ma rūf (ed.), Beirut, Dār al-Gharb al-Islāmī, 1422/2001, 17 vols.

al-Rāmahurmuzī, al-Muhaddith al-fạṣil, Muḥammad 'Ajjāj al-Khaṭīb (ed.), Beirut, Dār al-Fikr, 1391/1971.

Ṣāliḥ ibn Aḥmad, Masā'il al-imām Aḥmad ibn Hanbal, Ṭāriq ibn 'Awaḍ Allāh ibn Muhammad (ed.), Riyadh, Dār al-Wațan, 1420/1999.

Ṣālih ibn Aḥmad, Sìrat al-imām Aḥmad ibn Hanbal, Fu'ād 'Abd al-Mun ‘im Ạ̣mad (ed.), Alexandria, Mu'assasat Shabāb al-Jāmi 'ah, 1984.

al-Shāfi $e^{1}$, al-Risālah, Aḥmad Muḥammad Shākir (ed.), Cairo, Maṭa at Muṣțafā al-Bābī l-Halabī wa-Awlādih, 1358/1940; repr. Beirut, n.p., n.d.

al- 'Ulaymī, al-Manhaj al-aḥmad fi tarājim aṣhāo al-imām Aḥmad, 'Abd al-Qādir al-Arnā'ūt et al. (ed.), Beirut, Dār Șādir, 1997, 6 vols.

al-'Uqaylī, Kitāb al-Ḍu 'afā' al-kabīr, 'Abd al-Mu țī Amīn Qal'ajī (ed.), Beirut, Dār al-Kutub al-'Ilmìyah, 1404/1984, 4 vols.

Yāqūt, Irshād al-arīb, D.S. Margoliouth (ed.), Leiden, E.J. Brill, 1907-27, E.J.W. Gibb memorial series, 6, 7 vols.

Yāqūt, Irshād al-arīb, Iḥsān 'Abbās (ed.), Beirut, Dār al-Gharb al-Islāmī, 1993, 7 vols.

\section{Bibliography}

Abbott, Nabia, Studies in Arabic literary papyri 2: Qur'anic commentary and tradition, Chicago, University of Chicago Press, 1967, University of Chicago Oriental Institute publications, 76.

Abū Bakr ibn Latị̂ Kāfì, Manhaj al-imām Ahmmad fì l-ta'līl, Muhammad 'Abd al-Nabī (ed.), Beirut, Dār Ibn Hazm, 1426/2005.

Berg, Herbert, The development of exegesis in early Islam, Richmond, Surrey, Curzon, 2000, Curzon studies in the Qur'ān.

Brockopp, Jonathan, "Rereading the history of early Mālikī jurisprudence," Journal of the American Oriental Society, 118 (1998), pp. 233-238.

Brown, Jonathan A.C., Hadith, Oxford, Oneworld, 2009, Foundations of Islam. 
Cook, Michael, "The opponents of the writing of tradition in early Islam," Arabica, 44 (1997), pp. 437-530.

Crone, Patricia, "What do we actually know about Mohammed?," openDemocracy, 10 June 2008, available at http://www.opendemocracy.net/faitheurope_islam/mohammed_3866.jsp (accessed 25 February 2014).

Dickinson, Eerik, The development of early Sunnite hadith criticism, Leiden, Brill, 2001, Islamic history and civilization, Studies and texts, 38.

Dutton, Yasin, The origins of Islamic law, Richmond, Curzon, 1999, Culture and civilization in the Middle East.

Goody, Jack and Watson, Ian, "The consequences of literacy," Comparative studies in history and society, 5 (1962-3), pp. 304-345.

Günther, Sebastian, "Praise to the book! Al-Jāhiz and Ibn Qutaybah on the excellence of the written word in medieval Islam," Jerusalem studies in Arabic and Islam, 32 (2006), pp. 125-143.

Judd, Steven C., Religious scholars and the Umayyads, Abingdon, Routledge, 2014, Culture and civilization in the Middle East, 40.

Melchert, Christopher, Ahmad ibn Hanbal, Oxford, Oneworld, 2006.

Melchert, Christopher, "Early renunciants as hadith transmitters," The Muslim world, 92 (2002), pp. 407-418.

Motzki, Harald, "Dating Muslim traditions," Arabica, 52 (2005), pp. 204-253.

Motzki, Harald, The origins of Islamic jurisprudence, Marion H. Katz (trans.), Leiden, Brill, 2002, Islamic history and civilization, studies and texts, 41.

Ong, Walter J., Orality and literacy, New York, Routledge, 1982.

al-Qāḍī, Wadād, "Scholars and their books: a peculiar view from the fifth/eleventh century," Journal of the American Oriental Society, 124 (2004), pp. 627-640.

Rosenthal, Franz, "Of making many books there is no end," in George N. Atiyeh (ed.), The book in the Islamic world, Albany, State University of New York Press, 1995, pp. 33-55.

Schoeler, Gregor, "Die Frage der schriftlichen oder mündlichen Überlieferung der Wissenschaften im frühen Islam,” Der Islam, 62 (1985), pp. 201-230.

Schoeler, Gregor, "Schreiben und Veröffentlichen. Zu Verwendung und Funktion der Schrift in den ersten islamischen Jahrhunderten," Der Islam, 69 (1992), pp. $1-43$.

Schoeler, Gregor, The genesis of literature in Islam: from the aural to the read, Shawkat M. Toorawa (rev. and trans.), Edinburgh, Edinburgh University Press, 2009, The new Edinburgh Islamic surveys.

Schoeler, Gregor, The oral and the written in early Islam, Uwe Vagelpohl (trans.), James E. Montgomery (ed.), London, Routledge, 2006, Routledge series in Middle Eastern literatures, 13.

Sezgin, Fuat, Geschichte des arabischen Schrifttums, Leiden, E.J. Brill, 19672000, 11 vols. 
Speight, Marston, "A look at variant readings in the hadith," Der Islam, 77 (2000), pp. 169-179.

Speight, Marston, "Narrative structures in the Hadith," Journal of Near Eastern studies, 59 (2000), pp. 265-271.

Speight, Marston, "Rhetorical argumentation in the hadith literature of Islam," Semeia, 64 (1993), pp. 73-92.

'Umar, Bashīr 'Alī, Manhaj al-imām Ahmad fì i'lāl al-hadìth, Riyadh, Waqf al-Salām al-Khayrī, 1425/2005, Silsilat al-iṣdārāt al- 'ilmìyah, 2, 2 vols.

Recibido: 01/08/2013

Aceptado: 21/01/2014 